\title{
Economic and Toxicological Aspects of Pesticide Management Practices: Empirical Evidence from Turkey
}

\author{
Hasan Yilmaz ${ }^{1^{*}}$ \\ ${ }^{1}$ Isparta University of Applied Sciences, Faculty of Agriculture, Department of Agricultural \\ Economics, 32260, Isparta, Turkey. \\ *Corresponding Author e-mail: hasanyilmaz@isparta.edu.tr
}

Keywords: chickpea, pesticide practices, economic, toxicological, Turkey

\begin{abstract}
The aim of this study was to evaluate the economics and toxicological aspects of pesticide management practices for sustainable chickpea production. The results of this study demonstrated that the average usage of pesticides is $877.30 \mathrm{~g}$ per hectare as an active ingredient in the chickpea growing. The average usages per hectare of active ingredient of insecticides, fungicides, and herbicides were calculated to be $1.50 \mathrm{~g}, 638.80 \mathrm{~g}$, and $237.00 \mathrm{~g}$, respectively. Fungicides are the biggest pesticide group used with $72.81 \%$ of total weight of active ingredients. It was calculated that the crop protection cost was EUR 75.65 per hectare, having the portion of $12 \%$ of average production cost. The study revealed that the most common pesticides used by the farmers in chickpea growing were moderately hazardous and non-acute hazard categories. Based on the results of this study, it is suggested that the government should carry out effective agroenvironmental intervention policies and farmer extension programs should be aimed at balancing the amounts of pesticides used per hectare for the sustainable, dynamic environment and prevention of pesticide toxicity.
\end{abstract}

\section{Introduction}

Pesticide usage is a major component of the overall crop production system and is generally recognized as a necessary input in order to remain productive, economic and competitive. Despite such environmental, economic and health costs of pesticides, farmers continue to use pesticides [1, $2,3,4]$.

The use of pesticides requires assessment of the economic feasibility and safety for human health and environment, social consciousness and international cooperation and competitiveness [5]. Economic instruments can play a significant role in the achievement of objectives relating to the sustainable use of pesticides. In European Union developed action for the sustainable use of pesticides for plant protection products with the aim of harmonized social environmental and economic impact [6]. For sustainable use of pesticides is necessary to conduct education for safety data of pesticide application, control of tools and machine and best practice of pesticides application, monitoring of risk and benefits of the appropriate use of pesticides, rules of disposal of pesticides products after their use phase and of their packaging.

Chickpea is a product of economic importance legume crop grown in both Turkey and the world. According to 2015 FAO statistics, chickpea production in the world was realized in 13.7 million tones. The most important share in production belongs to India $(71.9 \%)$, Australia (4.6\%), Myanmar (4.0\%), Ethiopia and Turkey (3.3\%) and Pakistan (2.9\%), respectively [7]. The production and consumption are also localized in Asia. All of the above mentioned countries are important producers and consumers of chickpea. Among pulse crops marketed as human food, world chickpea consumption is second only to dry beans.

India stands out from the rest of the countries because of its high per capita consumption and especially its large population. These factors combined make India the top consumer chickpea market in the world. In terms of the market size, Pakistan and Turkey follow. Most of the countries with the highest chickpea consumption are developing countries [8]. 
In Turkey, total chickpea production was 450 thousand tons produced. Total chickpea production was 17 thousand tons in Isparta province. Its share in the total chickpea production of Turkey is $3.81 \%$. About $44.20 \%$ of total legume production was chickpea in Turkey [9]. Chickpea occupies the prime position both in area and production among the legume crops in the Isparta Province.

The main reason for growing chickpea such a wide range is due to be one of the highest nutritional valued crops of any of the dry legumes [10]. Chickpea is successfully grown under dry conditions in arid areas in Isparta and Turkey. In most part of Turkey, Chickpea is generally grown throughout the winter and spring as a rained crop and suffers from water shortage during seed development in spring [11]. In addition, chickpea is used successfully in the reduction of fallow lands and crop rotation systems. Agronomic applications are essential for high yield and quality of chickpea growing $[12,13]$.

The economic growth of chickpea depends from the agronomic, technical and economical measure of growing which contribute prevention of losses in crop yield. In chickpea production, the application of pesticides is one of significant measure in crop protection of attack of pests and diseases that can cause yield loss.

The aim of this study was to examine the economics and toxicological aspects of pesticide management practices for sustainable chickpea production. Also, farmers' environmental attitudes toward their use of pesticides, their pesticide used practices and problems were determined. There is limited available information about the economic evaluation of pesticide use in chickpea production in Turkey. In order to fill this information gap, there is a need for this study.

\section{Material and Method}

\section{Data collection}

The primary data for the study were collected using a set of structured and pre-tested questionnaires, which were administered to the Chickpea farmers of the study area. This study was conducted using a face to face interview with 31 Chickpea farmers from Gelendost and Yalvac districts of the Isparta province in Turkey and their villages were chosen as the study area where there is intensive Chickpea production. Chickpea is the most important crop grown in farms in these villages. The farms were chosen by simple random sampling method [14].

\section{Data Analysis}

All data were analyzed using SPSS software and procedures. Descriptive and inferential statistics were used to analyze the data collected. Demographic characteristics of farmers were analyzed using percentages and frequencies. For the economic cost of the pesticide the formula below was used (Eq.1):

$$
\mathrm{EC}=\mathrm{APAIU} * \mathrm{PPUPT},
$$

where:

EC: Economic cost (EUR ha- $\left.{ }^{1}\right)$;

APAIU: Amount of pesticide active ingredient used $\left(\mathrm{g} \mathrm{ha}^{-1}\right)$;

PPUPT: Price of pesticide used by pesticides type (1 / EUR).

Additionally, the gain threshold can be calculated with the following formula (Eq.2); Gain threshold $\left(\mathrm{kg} \mathrm{ha}^{-1}\right)=$ pesticide and pesticide application costs $\left(\right.$ EUR ha $\left.{ }^{-1}\right)$ : average chickpea price EUR kg-1).

Furthermore, pesticides were grouped by their toxicity classification and their chemical family based on the WHO criteria [15]. 


\section{Result and Discussion}

\section{Main characteristics of farmers' and their environmental awareness in chickpea growing}

The average age of the farmers was 46.2 years and the average experience of farmers in chickpea was 25.0 years. The average household size was 5 people. Farmers' average years of education was 7.4 (Table 1). The percentage of farmers who used agricultural credit was 35.5\%. The percentage of farmers who are members in agricultural cooperative was calculated as $71.0 \%$. The average farm size and cultivated areas were 14.0 ha and 13.7 ha, respectively. It was found that farms who were farming under non-irrigated area were $91.4 \%$ of farm size. The average cultivated area of the farms was 13.7 ha of which $22.6 \%$ was devoted to chickpea (3.1 ha) production (Table 1). In the study area, $74.2 \%$ farmers rely only on chickpea production as they do not have any other occupation, while the rest of the farmers were engaged in some other professions.

The rate of farmers who watched the agriculturally related programmes on television was calculated as $93.6 \%$ and used the internet for agricultural purposes was $29.0 \%$. The rate of farmers who want to produce by using the environmentally friendly techniques was $87.1 \%$. It was determined that $41.9 \%$ of the farmers participated in related with chickpea production extension programme. The percentage of farmers who participated in related with plant protection extension programme was $29.3 \%$. It was determined that $64.5 \%$ of the farmers used protector pesticide against pests and diseases. The rate of farmers who know about biological control in agricultural combat and known useful insects were $6.5 \%$ and $35.5 \%$, respectively (Table 1 ).

Table 1. Main characteristics and farmers' environmental awareness and information-seeking behaviors in chickpea growing.

\begin{tabular}{|c|c|c|c|}
\hline Indicators & Average & $\begin{array}{l}\text { Standard } \\
\text { Deviation }\end{array}$ & $\%$ \\
\hline \multicolumn{4}{|l|}{ Personal characteristics } \\
\hline Farmer's age (years) & 46.2 & 12.231 & - \\
\hline Farmer's education(years) & 7.4 & 2.904 & - \\
\hline Farmer's experience (years) & 25.0 & 12.938 & - \\
\hline Number of people in the family & 5.0 & 1.892 & - \\
\hline The rate of the farmer membership of agricultural cooperative $(\%)$ & - & - & 71.0 \\
\hline The number of the people working on crop production in family & 4.8 & 1.167 & - \\
\hline The rate of farmer dealing with non-agricultural activity & - & - & 25.8 \\
\hline The rate of farmer use agricultural credit & - & - & 35.5 \\
\hline \multicolumn{4}{|l|}{ Farm characteristics } \\
\hline Average farm size (hectare) & 14.0 & 18.161 & 100.0 \\
\hline Cultivated area (ha) & 13.7 & 18.223 & 97.9 \\
\hline Fallowing area (ha) & 0.3 & 0.791 & 2.1 \\
\hline Irrigated area (ha) & 1.2 & 1.360 & 8.6 \\
\hline Non-irrigated area (ha) & 12.8 & 17.387 & 91.4 \\
\hline Owned land (ha) & 9.3 & 5.885 & 66.4 \\
\hline Rented land (ha) & 4.7 & 15.978 & 33.6 \\
\hline Chickpea area (ha) & 3.1 & 3.430 & 22.6 \\
\hline Other crops production area (ha) & 10.6 & 15.136 & 77.4 \\
\hline \multicolumn{4}{|l|}{ Farmers' environmental awareness and information-seeking behaviors } \\
\hline $\begin{array}{l}\text { The rate of farmers wants to produce by using the techniques environmentally } \\
\text { friendly }(\%)\end{array}$ & - & - & 87.1 \\
\hline The rate of farmers watches TV programmes related agriculture $(\%)$ & - & - & 93.6 \\
\hline The rate of farmers use internet for agricultural purposes $(\%)$ & - & - & 29.0 \\
\hline The rate of farmers participated any meeting about chickpea production $(\%)$ & - & - & 41.9 \\
\hline $\begin{array}{l}\text { The rate of farmers participated any extension programmes related with plant } \\
\text { protection }(\%)\end{array}$ & - & - & 29.3 \\
\hline The rate of farmers knows about biological control in agricultural combat $(\%)$ & - & - & 6.5 \\
\hline The rate of farmers knows useful insects $(\%)$ & - & - & 35.5 \\
\hline The rate of farmers use protector pesticide against pests and diseases $(\%)$ & - & - & 64.5 \\
\hline
\end{tabular}

Source: author's calculations based on farmer survey data 


\section{Pests and diseases encountered by chickpea farmers in the research area}

Table 2 shows the major pests and diseases encountered by chickpea farmers. Insects, disease, and weeds cause significant yield and quality losses in chickpea production. Diseases and weeds are the most important limiting factors in chickpea growing in the research area. The research results showed that the majority of these farmers faced with pests, weeds and diseases include; Antrachnose (Ascochyta rabiei), Fusarium wilt (Fusarium oxysporum f.sp. ciceris), Rhizoctonia root rot, Liriomyza cicerina, Heliothis viriplaca, Amaranthus retroflexus, Sinapis arvensis and Cichorium intybus L., respectively. These pests, weeds, and diseases, cause economic losses in some chickpea fields in the study area. Pesticides, one option to combat pest, weeds and diseases damage and it have contributed to the high yield of chickpea production in Turkey.

Table 2. The major pests, weeds, and diseases in chickpea growing in the research area.

\begin{tabular}{lccc}
\hline Pests, Diseases, and Weeds & $\mathbf{N}^{*}$ & $\mathbf{\%}$ & Rank \\
\hline Antrachnose (Ascochyta rabiei) & 23 & 74.19 & I \\
Fusarium wilt (Fusarium oxysporum f.sp. ciceris) & 15 & 48.39 & II \\
Rhizoctonia root rot & 12 & 38.71 & III \\
Liriomyza cicerina & 11 & 35.48 & IV \\
Heliothis viriplaca & 8 & 25.81 & V \\
Amaranthus retroflexus & 7 & 22.58 & VI \\
Sinapis arvensis & 6 & 19.35 & VII \\
Cichorium intybus L. & 5 & 16.13 & VIII \\
\hline
\end{tabular}

Source: author's calculations based on farmer survey data. *Multiple responses

\section{Toxicity classes and types of the pesticides used by the farmers in chickpea growing}

There are many different types of pesticides; each is meant to be effective against specific to weeds, insect, and diseases. Some of these pesticides are also very important for environmental protection and human health. Table 3 shows an overview of all types of pesticides used by the farmers in chickpea growing in the research area. Pesticides were grouped by their toxicity classification and their chemical family [15]. Among the examined chickpea farmers, 8 different types of pesticides were used. Among the farmers, 3 different types of insecticides were used. The insecticides commonly used by the farmers were identified as Deltamethrin (54.84\%), Chlorpyrifos ethyl $(6.45 \%)$ and Fenvalerate used by $16.13 \%$ of the farmers.

Among the examined farmers, 2 different types of fungicides were used. The fungicides commonly used by the farmers were identified as Thiram used by $\% 67.74$ and Mancozeb used by $19.35 \%$ of the farmers as protection from fungal diseases in chickpea production. The most common herbicides in chickpea production are Aclonifen (70.97\%), 2,4-D Imazethapyr (6.45\%) and Isooctylester $(3.23 \%)$. The study revealed that the most common pesticides used by the farmers in chickpea growing were moderately hazardous and non-acute hazard categories.

Pesticides have been reported to have some side effects such as toxicity, environmental pollution, plant disease and pest resistance and resurgence high cost and unavailability at critical periods $[3,16,17]$. In order to reduce the side effects of pesticides used by farmers, there is a need to search for alternatives for pesticides. Pesticides used by farmers should be pest-specific, nontoxic to humans and other biotas, biodegradable, less prone to pests and diseases resistance, relatively less expensive and with the relative ease of application [16, 18]. Also, it has been reported to have environmental, health, and economic benefits of pest and disease control methods such as organic farming, good agricultural practices, integrated pest management and biological control [19]. Therefore, farmers should be encouraged with subsidy policies to use these pest and disease control methods, and farmer training activities should be carried out for the long-term benefits that will decrease to toxicological risks and increase economic, human, and environmental health [17]. 
Table 3. Type of pesticides used in chickpea growing according to classified using the WHO hazard classifications*.

\begin{tabular}{|c|c|c|c|c|}
\hline Trade Name & Chemical family & Toxicity class $^{\text {a }}$ & $\begin{array}{c}\text { Number of } \\
\text { farmers }\end{array}$ & $\%$ \\
\hline \multicolumn{5}{|l|}{ Insecticides } \\
\hline Decis EC 2,5 & Deltamethrın & II & 17.0 & 54.84 \\
\hline Dursban 4 & Chlorpyrifos-ethyl & Not listed & 2.0 & 6.45 \\
\hline Sumicidin \% 20 EC & Fenvalerate & II & 5.0 & 16.13 \\
\hline \multicolumn{5}{|l|}{ Fungicides } \\
\hline $\begin{array}{l}\text { Thiflow } \\
\text { Pomarsol Forte } 80 \mathrm{WP}\end{array}$ & Thiram & II & 21.0 & 67.74 \\
\hline \multicolumn{5}{|l|}{ Herbicides } \\
\hline Mayceb M 45 & \%80 Mancozeb & $\mathrm{U}$ & 6.0 & 19.35 \\
\hline $\begin{array}{l}\text { Based } \\
\text { Challenge } 600\end{array}$ & Aclonifen & $\mathrm{U}$ & 22 & 70.97 \\
\hline Ester Ext & 2,4-D Isooctylester & Not listed & 1 & 3.23 \\
\hline Pursuit $100 \mathrm{SL}$ & Imazethapyr & $\mathrm{U}$ & 2 & 6.45 \\
\hline
\end{tabular}

Source: author's calculations based on farmer survey data. ${ }^{\text {a }}$ WHO $2010 *$ The WHO recommended classification of pesticides by hazard. Index. Classification of active pesticide ingredients $(\mathrm{Ia}=$ Extremely hazardous; Ib = Highly hazardous; II = Moderately hazardous; III = slightly hazardous; $\mathrm{U}=$ Unlikely to present acute hazard in normal use; $\mathrm{FM}=$ Fumigant, not classified; $\mathrm{O}=$ Obsolete as pesticide, not classified). c Multiple responses were possible as there were no limitations set up for farmers' choices

\section{Economic analysis of pesticide use in chickpea growing}

Sustainable agricultural production is of main importance in sustaining human needs and protecting the environment. Crop protection products constitute one of the most important inputs in agricultural production. Pesticides can help in securing and improving crop yields and quality of the obtained products resulting in increased farm and agribusiness income [20]. Economic costs of pesticide and amounts of pesticides used in chickpea growing are presented in table 4 . The calculations of this research show that the average usage of pesticides is $877.30 \mathrm{~g}$ per hectare as an active ingredient in the chickpea growing. The average usages per hectare of active ingredient of insecticides, fungicides, and herbicides were calculated to be $1.50 \mathrm{~g}, 638.80 \mathrm{~g}$, and $237.00 \mathrm{~g}$, respectively.

Fungicides are the biggest pesticide group used in chickpea growing. They accounted for $72.81 \%$ of total weight of active ingredients, followed by herbicides $(27.01 \%)$ and insecticides $(0.17 \%)$. It was determined that farmers use fungicides more than the recommended, herbicides and insecticides less than the recommended dosages of private pesticide dealers and extension staff and pesticide labels. Increased or decreased use of pesticides can lead to inefficient, crop and economic losses and environmental hazards.

It was calculated that economic cost was EUR 75.65 per hectare. The percentages of these costs are $79.32 \%, 19.75 \%$ and $0.93 \%$ for fungicides, herbicides, and insecticides, respectively.

Table 4. Economic costs of pesticide and amounts of pesticides used in chickpea growing.

\begin{tabular}{lccccc}
\hline \multirow{2}{*}{$\begin{array}{l}\text { Type of } \\
\text { Pesticides }\end{array}$} & Used amount & & $\begin{array}{c}\text { Recommended } \\
\text { amount }\end{array}$ & $\begin{array}{c}\text { Pesticides+ Pesticide } \\
\text { application costs }\end{array}$ \\
\cline { 2 - 6 } Insecticides & $\mathbf{( g - m l - c c ) / h a}$ & $\mathbf{\%}$ & $\mathbf{( g - m l - c c ) / h a}$ & $\mathbf{(} \mathbf{\ell} / \mathbf{h a})$ & $\mathbf{\%}$ \\
Fungicides & 1.50 & 0.17 & 2.30 & 0.71 & 0.93 \\
Herbicides & 638.80 & 72.81 & 595.40 & 60.00 & 79.32 \\
Total pesticides & 237.00 & 27.01 & 266.80 & 14.94 & 19.75 \\
\hline
\end{tabular}

Source: author's calculations based on farmer survey data 


\section{Production and plant protection costs in chickpea growing}

Table 5 shows cost indicators for production and pesticide application in chickpea growing in the research area. Crop protection costs of items such as wages, uniforms, equipment personnel engaged in plant protection and pesticides. In this study, the average production costs of chickpea growing were determined to be EUR $630.46 \mathrm{ha}^{-1}$. According to this study, the cost of crop protection (pesticide and pesticide application costs) per hectare was determined as EUR 75.65 having the portion of $12.00 \%$ of average production cost. In this study, the average yield for chickpea was determined to be $1385.16 \mathrm{~kg} \mathrm{ha}^{-1}$. It was calculated that pesticide and pesticide application costs and production costs were determined to be EUR $0.06 \mathrm{~kg}^{-1}$ and EUR $0.52 \mathrm{~kg}^{-1}$, respectively.

Table 5. Cost indicators for production and pesticide application in chickpea growing.

\begin{tabular}{lcc}
\hline Indicators & Mean & St.deviation \\
\hline A. Average yield $(\mathrm{Kg} /$ hectare $)$ & 1385.16 & 553.92 \\
B. Average Pesticides + Pesticide application costs $(€ / \mathrm{ha})$ & 75.65 & 42.33 \\
C. Average Pesticides + Pesticide application costs $(€ / \mathrm{kg}) \quad(\mathrm{C}=\mathrm{B} / \mathrm{A})$ & 0.06 & 0.05 \\
D. Average production costs $(€ / \mathrm{ha})$ & 630.46 & 145.49 \\
E. Average production costs $(€ / \mathrm{kg})(\mathrm{E}=\mathrm{D} / \mathrm{A})$ & 0.52 & 0.22 \\
F. The proportion of crop protection costs in average production costs $(\%)$ & 12.00 & - \\
$(\mathrm{F}=(\mathrm{B} / \mathrm{D}) * 100))$ & & \\
\hline
\end{tabular}

Source: author's calculations based on farmer survey data. *Standard Deviation

\section{The gain threshold of pesticide use on chickpea growing}

Gain thresholds levels of the pest population that, if left untreated, would result in reductions in revenue that exceed treatment costs. Gain thresholds are used to decide if pesticide treatments or other pest management practices are economically justified. The decision generally requires information on pest infestation levels from scouting or monitoring [21]. In this study, the gain threshold was also estimated for chickpea production. Gain thresholds are a simple way to determine the relationship between the pesticide and pesticide application costs and the value of the harvested crop. Gain thresholds are simply the pesticide and pesticide costs per area divided by the value per unit of harvested chickpea.

Average pesticide and pesticide application costs and average chickpea price were EUR $75.65 \mathrm{ha}^{-1}$ and EUR $0.71 \mathrm{~kg}^{-1}$, respectively. The gain threshold was calculated to be $106.55 \mathrm{~kg} \mathrm{ha}^{-1}$ and it was $7.69 \%$ of chickpea production per hectare. This means that the increase in yield, or gain, has to be $106.55 \mathrm{~kg} \mathrm{ha}^{-1}\left(7.69 \%\right.$ of chickpea production $\left.\mathrm{ha}^{-1}\right)$ for this pesticide use to be economic.

\section{Conclusion}

Application of the suitable pesticide in chickpea growing is important for optimal yield, economic benefit, and for preventing environmental pollution. Results of this research show that the average cost of chickpea production was EUR $630.46 \mathrm{ha}^{-1}$. The average usage of pesticides was $877.30 \mathrm{~g}$ per hectare as an active ingredient in chickpea growing. Fungicides are the biggest pesticide group used in chickpea growing. It was calculated that the average plant protection cost was EUR $75.65 \mathrm{ha}^{-1}$ and this represents $12 \%$ of chickpea growing costs. In analyses of the use of pesticides in chickpea growing in the examined farms indicated that the gain threshold was 106.55 $\mathrm{kg} \mathrm{ha} \mathrm{k}^{-1}$ what is $7.69 \%$ of chickpea production per hectare, what is economically justified. Several constraints barring the sustainable production of the traditional or local practices of chickpea crop in the research area. It is determined that farmers use fungicides more than the recommended dosages of private pesticide dealers and extension staff and pesticide labels. Unfortunately, this leads to economic loss, cost increase, and environmental problems. As a conclusion, it can be suggested that an integrated system is required in crop protection applications in chickpea growing in the research 
area for the sustainable and dynamic environment. Furthermore, the government should carry out effective agro-environmental intervention policies and farmer extension programs aimed at decreasing the amounts of pesticides used in the research area.

\section{Acknowledgments}

We acknowledge Scientific Research Projects Committee of Suleyman Demirel University (SDU BAP 2620-M-10) which provided us with the financial support of this study. The author expresses appreciation to farmers and other individuals who provided assistance.

\section{References}

[1] M. Smith, M.J. Poggio, M. Thompson, A. Collier. The Economics of Pesticide Management Practices on Sugarcane Farms: Final Synthesis Report. (2014). Department of Agriculture, Fisheries and Forestry (DAFF), Queensland. http://era.daf.qld.gov.au/id/eprint/4492/1/finsynth-rep-econ-pest-mgment-sc-farms.pdf.Accessed 17 April 2017

[2] N. Monfared, M.Yazdanpanah, K. Tavakoli. Why Do They Continue to Use Pesticides? The Case of Tomato Growers in Boushehr Province in Southern Iran. Journal of Agricultural Science and Technology, 17 (2018) 577-588.

[3] C.Wilson, C. Tisdell. Why Farmers Continue to Use Pesticides Despite Environmental, Health and Sustainability Costs?. Ecological Economics, 39 (3) (2001) 449-462.

[4] K. Atreya. Pesticide Use Knowledge and Practices: A Gender Differences in Nepal. Environmental Research, 104 (2007) 305-311.

[5] E.S. Sexton, Z. Lei, D. Zilberman. The Economics of Pesticides and Pest Control. International Review of Environmental and Resource Economics, (1) (2007) 271-326.

[6] European Commission (EC). Directive 2009/128/EC of The European Parliament And of The Counc1l of 21 October 2009 establishing a framework for Community action to achieve the sustainable use of pesticides, Official Journal of the European Union.(2009). 24.11.2009-L 309/71. http://eur-lex.europa.eu/LexUriServ/LexUriServ.do?uri= OJ:L:2009:309:007:00 86:en:PDF Accessed 27 October 2016

[7] Food and Agriculture Organization (FAOSTAT). The statistics division of the food and agriculture organization (2015). http://faostat.fao.org. Accessed 8 October 2016

[8] J.M. Garzon. The Production of Chickpea in Argentina: Current Status and Perspectives. Working Document, (2013). Year19 - Edition 120-19 April 2013. http://www.ieral.org/images_db/noticias_archivos/2576-The\%20Production $\% 20 \mathrm{of} \% 20$ Chickpea\%20in\%20Argentina.pdf Accessed 22 Nov 2016

[9] Turkish Statistical Institute (TURKSTAT). Turkish statistical institute, crop production statistics. (2016). http://www.tuik.gov.tr. Accessed 10 Nov 2017

[10] E. Ceyhan, M. Harmankaya, M.A. Avc1. Effects of Sowing Dates and Cultivars on Protein and Mineral Contents of Bean (Phaseolus vulgaris L.). Asian Journal of Chemistry, 20(7) (2008) 5601-5613.

[11] S.O. Ozgun, T.B. Bicer, D. Sakar. Agronomic and Morphological Characters of Chickpea Under Irrigated Conditions in Turkey. International Journal of Agriculture and Biology, 6(4) (2004) 606-610.

[12] M. Sayıl1, H. Akca, O. Ozdemir. Functional analysis of fertiliser use on chickpea (Cicer arietinum) farms: a case study from Turkey. New Zealand Journal of Crop and Horticultural Science, 36 (2008) 131-136. 
[13] A. Kahraman, Z. Ozkan. Ascochyta Blight of Chickpea. Selcuk Journal of Agriculture and Food Sciences, 29(2) (2015) 62-66.

[14] T. Yamane. Basic Sampling Methods. In: Translators, Esin, A., M.A. Bakir, C. Aydin and E. Gurbuzsel (Eds.). (2001) Literatur Publishing, Istanbul.

[15] World Health Organization (WHO). The WHO Recommended Classification of Pesticides by Hazard and Guidelines to Classification, 2009. (2010). International Programme on Chemical Safety. ISSN 1684-1042.

[16] A.F. Odewole, T.A. Adebayo. Field evaluation of plant extracts for the control of diamond moth (Plutella xylostella Linnaeus) infesting Cabbage (Brassica oleracea Linn). International Letters of Natural Sciences, 16 (2014) 164-178.

[17] H. Y1lmaz. Economic Analysis of Pesticides Management for Effective Agro-Environmental Policy in Context of Sustainable Rural Development. Proceedings of the 10th International Workshop on Regional Innovation Studies (IWRIS2018), (2018) 91-95, Mie University, Japan.

[18] S.O. Duke. Natural pesticides from plants. In Janick J and simon J.E Eds. Advances in new crops. Timber Press, Portland, (1990) 511-517.

[19] H. Yilmaz, Z.A. Tanc. Biological control in pest management in Turkey: Comparison of the attributes of participant and non-participant greenhouse farmers in government-subsidized biological control practices. Future of Food: Journal on Food, Agriculture and Society, 7(2), (2019) Article Nr. 105.

[20] J. Cooper, H. Dobson. The benefits of pesticides to mankind and the environment. Crop Protection, 26 (2007) 1337-1348.

[21] L.P. Pedigo, L.G. Higley. Introduction to Pest Management and Thresholds. In Economic Thresholds for Integrated Pest Management. University of Nebraska Press, Lincoln. (1996) 39. 